\title{
Influence of the Colorless Waste Glass on the Mineralogical, Microstructural and Mechanical Properties of Clay Material from Wack (Adamawa, Cameroon)
}

\author{
Souaibou1, Elimbi Antoine², Danwe Raidandi1 \\ ${ }^{1}$ Department of Civil Engineering and Architecture, The National Advanced School of Engineering, Maroua, Cameroun \\ ${ }^{2}$ Department of Inorganic Chemistry, Faculty of Sciences, University of Yaounde I, Yaounde, Cameroon \\ Email: souelma@yahoo.fr, aelimbi2002@yahoo.fr, rdanwe@yahoo.fr
}

How to cite this paper: Souaibou, Antoine, E. and Raidandi, D. (2019) Influence of the Colorless Waste Glass on the Mineralogical, Microstructural and Mechanical Properties of Clay Material from Wack (Adamawa, Cameroon). Advances in Materials Physics and Chemistry, 9, 89-102. https://doi.org/10.4236/ampc.2019.95008

Received: March 22, 2019

Accepted: May 27, 2019

Published: May 30, 2019

Copyright $\odot 2019$ by author(s) and Scientific Research Publishing Inc. This work is licensed under the Creative Commons Attribution International License (CC BY 4.0).

http://creativecommons.org/licenses/by/4.0/

\begin{abstract}
This study reports the investigation of the influence of adding waste glass on the properties of fired clay specimen. Four different particle sizes (smaller than $100 \mu \mathrm{m}, 300 \mu \mathrm{m}, 500 \mu \mathrm{m}$, and $800 \mu \mathrm{m}$ ) of waste glass were mixed with a clay material at contents of $0 \%, 2 \%, 6 \%$ and $10 \%$ per weight. Specimen samples were fired at $750^{\circ} \mathrm{C}$ in an electrical furnace for 6 hours, at a heating rate of $5^{\circ} \mathrm{C} / \mathrm{min}$. The physical and mechanical properties of terracotta are studied. The chemical analysis revealed that the clays were dominated by kaolinite and montmorillonite with small proportion of mixed layers clay. The fine grained texture $(0.002 \mathrm{~mm}>25 \%)$ and high plasticity $\left(\mathrm{W}_{\mathrm{P}}>30 \%\right)$ of the clays were responsible for the moderate and high values of shrinkage upon oven drying and firing. The firing color variation from reddish brown shade was due to the amounts of iron and titanium oxides present in the obtained material. The water absorption was varied between $17.40 \%$ and $13.70 \%$, while the linear shrinkage was estimated to be between $0.70 \%$ and $1.20 \%$ and the flexural strength from 5.30 to $8.10 \mathrm{MPa}$. These results showed that mixing clay with waste glass at $750^{\circ} \mathrm{C}$ is an interesting approach to obtain reddish brown ceramics destined for bricks or roofing tiles.
\end{abstract}

\section{Keywords}

Clay Materials, Waste Glass, Terracotta, Physical and Mechanical Properties

\section{Introduction}

The term clay is generally referred to the fine grained earth materials with par- 
ticles less than two microns $(2 \mu \mathrm{m})$, of hydrous aluminum silicate minerals groups which are characterized by sheet silicate structure of composite layers stacked along the $c$-axis [1]. Clays are known as the main raw material exploited in the manufacture of various ceramic products used as building materials. Because of their inherently complex physic, chemical and mineralogical characteristics, clays exhibit unique properties related to their own nature genesis [2] [3]. Generally, the ceramic industry for economic reasons relies on clays from nearby deposits. Therefore, the clay materials analysis and characterization are important for the performance of local material [4].

However, the most promising developments in the ceramic industry are related to processes that consume less energy. In fact, good quality terracotta requires high fired temperature (over $1100^{\circ} \mathrm{C}$ ) and thus more expensive. It is therefore essential to find methods that can lower the fired temperature.

Significant energy savings are expected in the crushing/grinding, drying and fired stages if a careful choice of raw materials is made. Everything is then implemented to optimize the thermal cycle by reducing the fired time either by a high rate of rising in temperature or by reducing the sintering temperature. The ceramic paste formulation can be adjusted accordingly to the fast firing by reducing the sintering temperature. This requires the use of fluxes (feldspar, talc) or the alkaline ions which will induce the formation of eutectic which could allow lowering the melting temperature. Thus, the firing temperature of the clay pastes is substantially reduced by the use of these fluxes. It is possible that these fondants have a high price.

The present work aims at the use of a colorless waste glass of recovery as an adjunct in the formulation of clay pastes. It is about getting products at relatively low firing temperatures $\left(750^{\circ} \mathrm{C}\right)$ with respect to energy costs in our developing countries. To achieve this goal, clay material were mixed at specific percentage and fired at $750^{\circ} \mathrm{C}$. The obtained material wax characterized in term of chemical composition using X-ray fluorescence spectrometry, structure using X-ray diffraction (XRD) and Infra-red spectroscopy (IR). The microstructure or morphology were analyzed using scanning electron microscopy (SEM). In addition, some technological properties such as the linear shrinkage, flexural strength and water absorption were performed.

\section{Geological Setting}

The studied clay raw material were collected in the northern part of Ngaoundéré, located in the Adamawa region (Cameroon), and which is characterized by a Sudano Sahelian climate (precipitation between 1200 and 1500 $\mathrm{mm}$ /year). The Adamawa region is a vast plateau with gentle slope to the South and steep side at the North. From the South to North, altitude increase slowly and in a regular manner until around Meiganga locality where it begins at the Adamawa plateau with elevations between 1000 and $2000 \mathrm{~m}$ [5].

The most important mountains are: Guenfalabo, Tchabal Mbabo $(2460 \mathrm{~m})$ 
and Hossere Djinga Nganha (1923 m). On the tectonics plan, the region belongs to the Panafrican belt [5] [6]. It is characterized by the presence of many shear zones oriented North East-South West (NE-SW) including the Shear Cameroonian Centre [6]. The geological diversity of this region is marked by the presence of granites at the border with Nigeria, metamorphic rocks (micashistes, schist and gneiss) covered with volcanic rocks at East of the Gotel Mountains and North East of Ngaoundéré and sedimentary rocks in Mbéré valley [7] [8] (Figure 1).

The detailed geological formations situated on the Ngaoundéré West uplift were been reported elsewhere [5]. They are mostly coarse grain granite of pink or white Feldspars and scarcely diorites. They are identified around Wack locality and elongated bands at the Northern Wack near Karna Manga. Metamorphic rocks which constitute the substratum of the Wack Regions. They are orthogneiss, gneiss and migmatite on which slabs of amphibolites appear. Some dykes of dolerite are also present. The elongated bands are in alternance with the plutonic rocks. These types of rocks show a great variety in structure, composition and properties. Sedimentary rocks are constituted by metamorphic conglomerate and sandstones. They are localized in the entire Benoué basin [8].

Pedological formations of the Adamawa region are clays, alluvium sands and rarely of plain, arena (clayey sand and sandy soils), lateritic soils (laterites and graves). Clays are the weathered materials from rocks. The clays observed in the Adamawa region are estimated about $141,000,000 \mathrm{~m}^{3}$ available in various sites [8]. The clay deposits within Vina Division generally, and Mbé Subdivision, in particular, are swampy clay which is subject to inundations during flooding in the wet season. The clay layers are overlain by $1-1.5 \mathrm{~m}$ of very loose horizons of mixtures of partly decomposed vegetation, mud, silt and fine sand. The clay layers

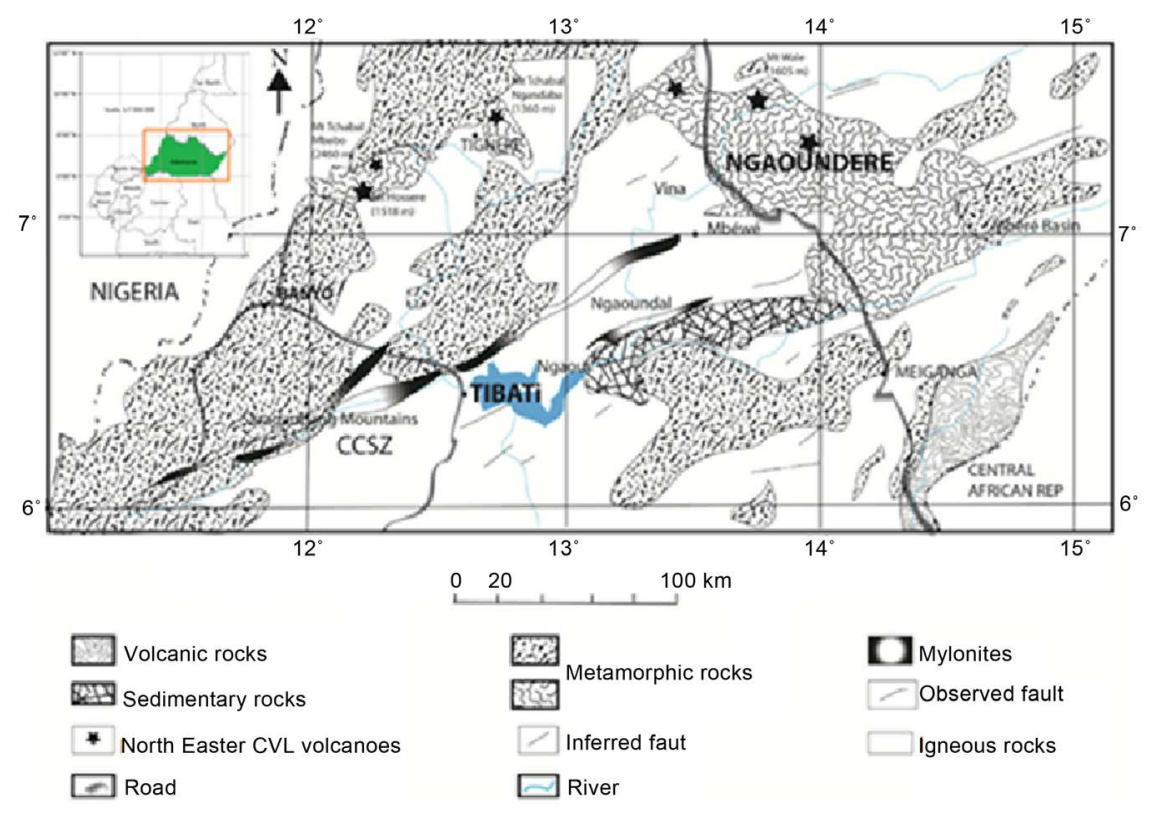

Figure 1. Geological map of Adamawa region (in [8] modified). 
which are $1.5-3 \mathrm{~m}$ thick are not laterally continuous and they are usually interbedded with thin sandy facies. The natural moist color of the clay vary from light/dark grey to black with the latter turning brown or brownish grey when exposed to the sun. This is due to the oxidation of ferrous iron oxide to ferric state.

\section{Materials and Methods}

\subsection{Materials}

The clay material in this investigation was collected from the area of Wack in the Vina Division (Adamawa Region of Cameroun). Two representative clay materials were sample there. Light grey $\left(\mathrm{W}_{1}\right)$ and dark grey $\left(\mathrm{W}_{2}\right)$ colored clay were first cured at room temperature for 2 weeks then dried at $105^{\circ} \mathrm{C}$ for $48 \mathrm{~h}$. The dried blocks were crushed and then ground in a ball mill and the resulted powder was sifted by using a $200 \mu \mathrm{m}$ mesh sieve.

The colorless waste glass bottles collected from garbage cans, were broken into pieces, washed and dried at $105^{\circ} \mathrm{C}$. The resulted particles were crushed then sieved at different grain size $(100 \mu \mathrm{m}, 300 \mu \mathrm{m}, 500 \mu \mathrm{m}$ and $800 \mu \mathrm{m})$.

\subsection{Experimental Methods}

Clays samples collected during field trips were subjected to standard laboratory analysis like particle size analyses (sieving and sedimentation) according to ASTM norm D422, Atterberg limits according to ASTM norm D4318. One type of addition was done (clay with waste glass powder) in order to improve the physical and chemical characteristics, thus giving the blocks great resistance after firing at $750^{\circ} \mathrm{C}$ [9]. The clay/waste glass powder ratio was done according to the following mixture: by varying the amount (percentage ranging between $0 \%$, $2 \%, 6 \%$ and $10 \%)$ and grain size $(100 \mu \mathrm{m}, 300 \mu \mathrm{m}, 500 \mu \mathrm{m}$ and $800 \mu \mathrm{m})$ of the additive. Before the production of compressed parallelepiped $(82 \mathrm{~mm} \times 42 \mathrm{~mm}$ $\times 9 \mathrm{~mm}$ ) and cylindrical (13 $\mathrm{mm}$ diameter and $9 \mathrm{~mm}$ height), then the samples were drying in the oven at $105^{\circ} \mathrm{C}$ for 48 hours; then particle less than $2 \mathrm{~mm}$ were used for making the mixture. Then fired in a kiln (Nabertherm, model LH $60 / 40)$ at $750^{\circ} \mathrm{C}$ at the rate of $5^{\circ} \mathrm{C} / \mathrm{min}$ for two hours. The firing temperature of $750^{\circ} \mathrm{C}$ was chosen as a result of preliminary test which showed that the used glass powder started to melt at around $700^{\circ} \mathrm{C}$

The mineralogical analysis of each sample collected was made by X-ray diffraction (XRD) using a Philip PW 3050/60 diffractometer which operated by reflection of $\mathrm{Ka}_{1}$ radiation of Copper. Semi-quantitative estimation of the amounts of the different minerals present in the sample was given measuring the diffraction peak height. Fourier transform infrared spectroscopy (FTIR) was performed with the aid of a Bruker Alpha-P, operating in absorbance mode. The microstructure of the samples was observed and analyzed using a HITACHI S-3600N scanning electron microscope (SEM). The Scanning Electron Microscope made it possible to observe the surface topography of a sample by scan- 
ning its surface by an electron beam and collecting the image formed. Since the samples are not conductive, metallization of the surfaces is necessary by covering them with a thin layer of gold. There are two methods to achieve this result. For this study, sputtering was used. It involves depositing on the sample atoms torn from a piece of metal (gold) by argon ionization in a partial vacuum chamber.

Linear shrinkage was determined on parallelepiped fired test specimens thanks to a caliper (ROCH France, Patented S.G.D.G.) and water absorption was carried out on cylindrical fired test specimens using NF-P-18-554 standard [10]. Flexural strength was performed according to EN-100 standard [11] on parallelepiped fired test specimens using an electro-hydraulic press ( $\mathrm{M} \& \mathrm{O}$, type 11.50, and No 21) operating at an average rate of $3 \mathrm{~mm} / \mathrm{min}$.

An electron microprobe wax employed to examine detailed mineral identification.

\section{Results and Discussions}

\subsection{Identification Tests}

The clays are fine grained and characterized by a high proportion $(>30 \%)$ of clay sized fractions. The proportion of sand is always less than $10 \%$. Close examination of sand particles revealed that they are made up of a mixture of quartz grains and iron concretions. The latter is the product of tropical weathering of the clays (Table 1).

The clays are all high plastic $\left(20 \%>\mathrm{I}_{\mathrm{P}}<40 \%\right)$ which can be attributed to the low percentage of sand particles and the presence of significant amounts of expandable mixed layer clays, montmorillonite and/or organic matter. In Wack, the potter that use some of these clay deposits for pottery wares, blend the clays with cohesionless granular sand to reduce the high plasticity and the expected excessive drying shrinkage and severe internal cracking on firing.

\subsection{Chemical and Mineralogical Composition of Samples}

\subsubsection{Clay Sample}

The chemical compositions of the clays $\left(\mathrm{W}_{1}\right.$ and $\left.\mathrm{W}_{2}\right)$ are presented in Table 2. These results are somewhat similar to those obtained by [12] for the relationship between sediments and their metamorphic source rocks from the region. These studied clays contain many high amounts of iron and titanium oxide than allowed. The high concentration of these oxides gives rise to pinkish, reddish and brownish firing colors which are in some ceramic industries. The high proportions of iron oxide $(>20 \%)$ in the clay deposits at Wack render them unsuitable

Table 1. Some identification tests of the studied clays.

\begin{tabular}{ccccccc}
\hline \multirow{2}{*}{ Samples } & \multicolumn{3}{c}{ Grading (\%) } & \multicolumn{3}{c}{ Plasticity (\%) } \\
\cline { 2 - 7 } & Sand & Silt & Clay & $\omega_{\mathrm{L}}$ & $\omega_{\mathrm{P}}$ & $\mathrm{I}_{\mathrm{P}}$ \\
\hline $\mathrm{W}_{1}$ & 5.4 & 32.1 & 57.5 & 58.0 & 28.6 & 29.3 \\
$\mathrm{~W}_{2}$ & 2.0 & 19.5 & 50.5 & 60.1 & 33.5 & 26.6 \\
\hline
\end{tabular}


Table 2. Chemical composition of the clays and waste glass.

\begin{tabular}{ccccccccccc}
\hline & $\mathrm{SiO}_{2}$ & $\mathrm{Al}_{2} \mathrm{O}_{3}$ & $\mathrm{Fe}_{2} \mathrm{O}_{3}$ & $\mathrm{TiO}_{2}$ & $\mathrm{CaO}$ & $\mathrm{MgO}$ & $\mathrm{K}_{2} \mathrm{O}$ & $\mathrm{Na}_{2} \mathrm{O}$ & $\mathrm{MnO}$ & $\mathrm{LOI}$ \\
\hline $\mathrm{W}_{1}$ & 50.20 & 23.30 & 9.40 & 1.37 & 0.98 & 1.27 & 3.63 & 0.88 & 0.17 & 8.08 \\
$\mathrm{~W}_{2}$ & 53.14 & 21.14 & 8.30 & 1.26 & 1.03 & 1.04 & 4.20 & 2.28 & $<0.10$ & 7.15 \\
$\mathrm{~W}_{\mathrm{G}}$ & 68.70 & 1.90 & 0.56 & $<0.10$ & 14.30 & 2.33 & 0.75 & 12.60 & $<0.10$ & 0.55 \\
\hline
\end{tabular}

LOI $=$ loss on ignition.

for ceramic industries with high mechanical value [9]. However, they are suitable for brick and pottery production.

Silica and alumina vary from $50.20 \%-55.71 \%$ to $21.14 \%-24.34 \%$ respectively. It is suggested that the clays are low to medium quality refractory varieties. Generally, the clays contain high amounts of alkali and magnesia (>1\%). The slightly higher amounts of lime $(\mathrm{CaO})$ in samples are attributed to the presence of carbonates. The clays from Wack contain also restively higher amounts (0.47 2.70) of sodium oxide which is most probably due to the significant proportions of montmorillonite in these samples. The low content of potassium oxide in the clays indicates the presence low amount of illite. Generally, the amounts of sodium and calcium oxides in most of the clays are much higher than the amounts required for ceramic production. The appreciable amounts of these two oxides will lower the vitrification of the clays, thereby making them unsuitable for manufacturing of refractory bricks.

The clays mineral assemblage comprises of kaolinite, montmorillonite, illite, goethite and halloysite. Kaolinite is the dominant clay mineral in most deposits. Quartz, anatase, albite and not/and or those are the main subsidiary non clay mineral detected from the XRD patterns and they are estimated to $15 \%-35 \%$ of most samples. The most significant amounts of montmorillonite in some of clays will result in high plasticity and shrinkage as well as low vitrification. These three properties are undesirable in the ceramic industries. That is why stabilization method was done to ameliorate the properties and quality of terracotta by adding waste glass powder [13].

The Fourier transform infrared spectroscopy (FTIR) spectrum of clays is shown in Figure 3. The absorption bands at $3694-3620 \mathrm{~cm}^{-1}$ express the stretching vibrations of ${ }^{-} \mathrm{OH}$ groups of kaolinite network [14] [15]. The bands located at 3402 and $1640 \mathrm{~cm}^{-1}$ correspond respectively to stretching vibrations of water molecules while those at 998 and $788 \mathrm{~cm}^{-1}$ express the vibration of Si-O-Al group of the network [16]. The bands at 909 and at $789 \mathrm{~cm}^{-1}$ indicate the stretching vibration of $\mathrm{Al}-\mathrm{OH}$ with $\mathrm{Al}$ in $\mathrm{VI}$ coordination. The band at $525 \mathrm{~cm}^{-1}$ indicates the vibration of Si-O-Si and Si-O-Al groups of the network [14] [15].

Figure 2 shows the microscopic microstructure of the two samples. The microscopic observation of the $\mathrm{W}_{1}$ and $\mathrm{W}_{2}$ samples shows that the texture is relatively compact, consisting of several superimposed planar sheets with a turbostatic disorder (random combination of rotations and translations). It is observed that the presence of some pores and microcracks. 

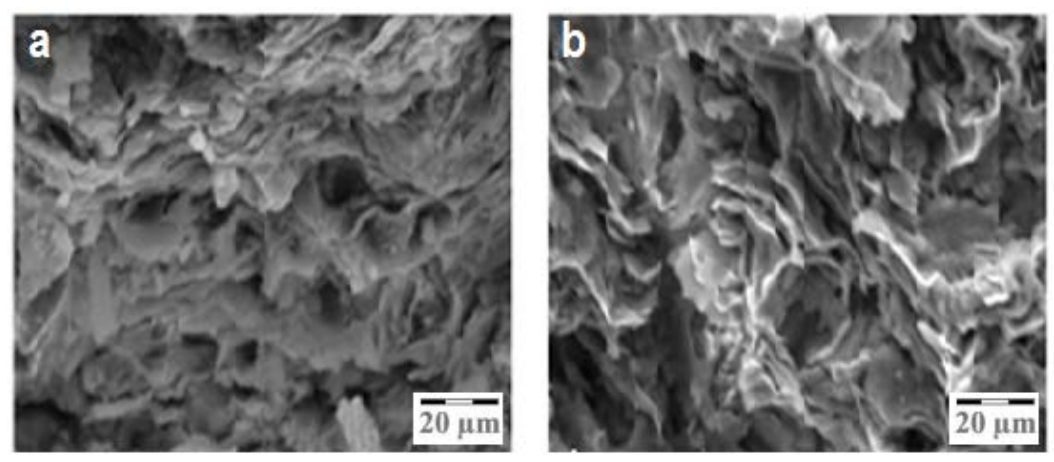

Figure 2. Microstructure of the raw material ((a) $\mathrm{W}_{1}$ and (b) $\mathrm{W}_{2}$ ).

\subsubsection{Waste Glass}

The chemical compositions of waste glass (WG) are presented in Table 2. The powder contains a high amount of silica $(68.70 \%)$ and a considerable quantity of $\mathrm{CaO}(14.30 \%)$ along with $\mathrm{Na}_{2} \mathrm{O}(12.60 \%)$ which enable to classify as soda-lime glass [16]. Considerable amount of $\mathrm{Na}_{2} \mathrm{O}+\mathrm{K}_{2} \mathrm{O}(13.35 \%)$ and $\mathrm{CaO}+\mathrm{MgO}$ $(16.63 \%)$ could act as energetic fluxing agent when added with the clay powder to get mixtures enabling to make associated products. Since waste glass has a little amount of colorizing oxides, mixing its powder with that of clay will result in no significant change of color of fired products [13]. Conversely, the presence of the above oxides in the mixtures will induce viscous flow phase to occur at relatively low temperature, since experimentally waste glass melts around $700^{\circ} \mathrm{C}$ [9]. According to this, waste glass material can constitute a potential fluxing agent that can substitute feldspar for manufacturing ceramics. The main effect of utilizing waste glass here is then to reduce energy consumption with a view to achieving economic purpose. In addition, waste glass replaces completely feldspar since the latter is expensive and not available everywhere for effective economic consumption while the former is easily found free especially in certain urban zones [14] [15] [16] [17] [18].

Figure 3 exhibits the Fourier transform infrared spectroscopy (FTIR) spectrum of waste glass $\left(\mathrm{W}_{\mathrm{G}}\right)$. The bands respectively at 949 and $433 \mathrm{~cm}^{-1}$ are fingerprint of quartz [15] [16] [17] [18] [19] while the one at $1472 \mathrm{~cm}^{-1}$ expresses the vibration of O-C-O and this could be in accordance with the raw materials commonly used for the making of soda lime-glass. Also the band at $772 \mathrm{~cm}^{-1}$ expresses the absorption of quartz inferring marks of crystalline silica within the great amount of amorphous phase of the soda-lime waste glass [20]. This is evidence of high amount content of silica as shown in the chemical composition of waste glass. The XRD pattern of waste glass is shown in Figure 4 and exhibits mainly a large dome between $20^{\circ}$ and $40^{\circ}(2 \theta)$ which expresses great amorphous silica content [21] of waste glass.

\subsection{Some Characteristics of the Fired Clays}

Five specimen tests were made from each formulation by adding the mixture of clay and waste glass powder by varying the amount and the grains size of the 


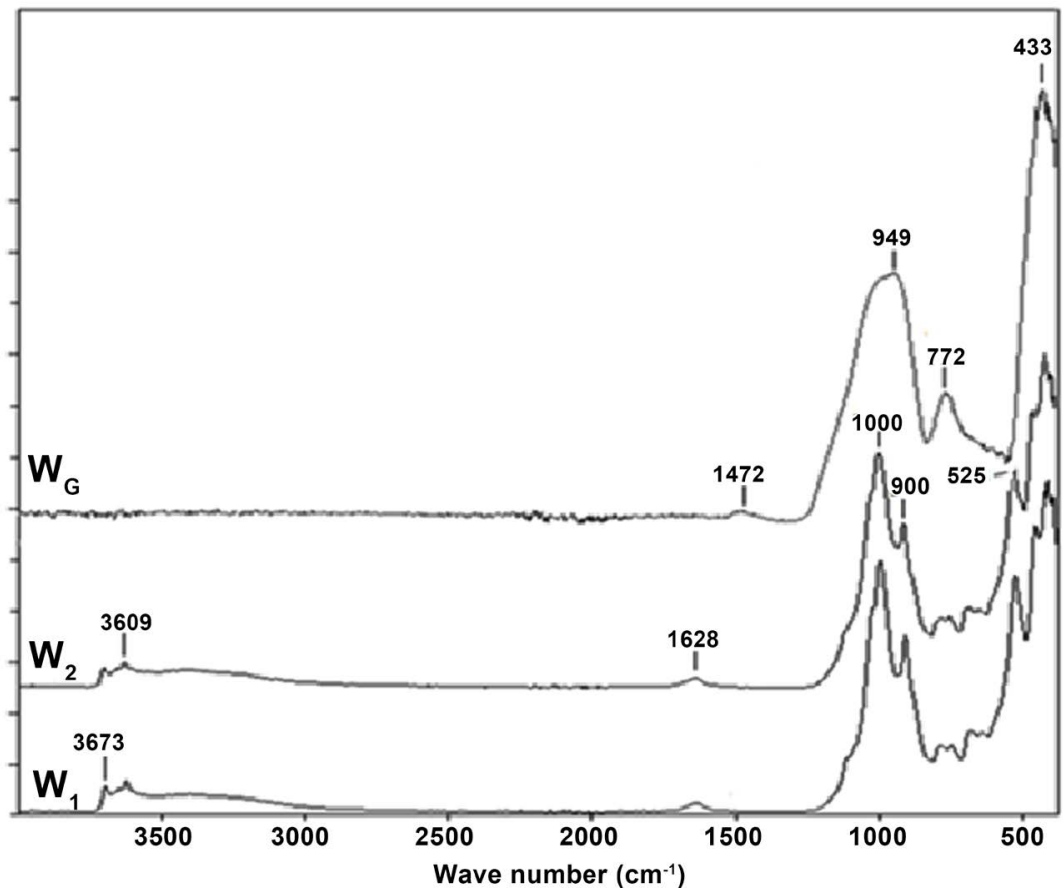

Figure 3. Infra-red spectrum of clays $\left(\mathrm{W}_{1}\right.$ and $\left.\mathrm{W}_{2}\right)$ and waste glass $\left(\mathrm{W}_{\mathrm{G}}\right)$.

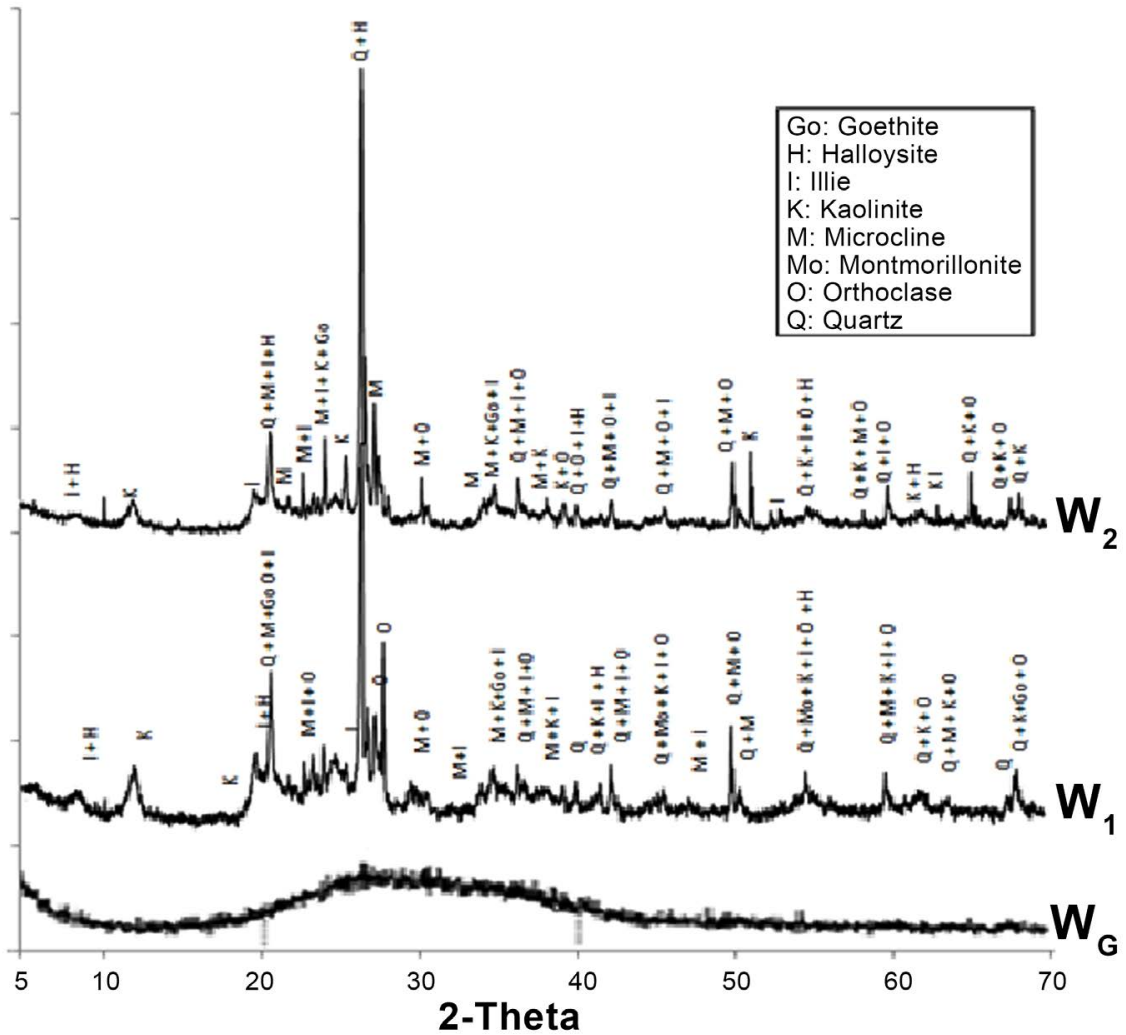

Figure 4. XRD patterns of clays $\left(\mathrm{W}_{1}\right.$ and $\mathrm{W}_{2}$ ) and waste glass (WG).

additive. These specimen after the determination of their physical properties, were fired in an electric furnace at predetermined temperatures. 
Some of the physical properties of the fired clays are presented in Table 3. All the clays exhibit color change when fired. One group of fired color was obtained, reddish brown color (Figure 5). This firing color is dependent on the amount of the oxide of iron and titanium present in the materials.

Linear shrinkage, water absorption and flexural strength of samples initially fired at $750^{\circ} \mathrm{C}$ are shown in Figure 6. Addition of waste glass leads to increase linear shrinkage from $0.24 \%$ to $1.70 \%\left(800 \mu \mathrm{m}, \mathrm{W}_{2}\right)$. This increase correlates with the chemical transformations which take place during the heating of the samples. The elimination of water content, allow the formation of new crystalline

Table 3. Some physical properties of the fired clays $\left(\mathrm{W}_{1}\right.$ and $\left.\mathrm{W}_{2}\right)$.

\begin{tabular}{|c|c|c|c|c|c|c|c|}
\hline Samples & $\begin{array}{c}\text { Waste Glass } \\
\text { Grain Size } \\
(\mu \mathrm{m})\end{array}$ & $\begin{array}{c}\text { Amounts of } \\
\text { Waste Glass } \\
(\%)\end{array}$ & $\begin{array}{l}\text { Moist } \\
\text { Color }\end{array}$ & $\begin{array}{l}\text { Firing } \\
\text { Color }\end{array}$ & $\begin{array}{c}\text { Water } \\
\text { Absorpt. } \\
(\%)\end{array}$ & $\begin{array}{c}\text { Linear Shr. } \\
(\%)\end{array}$ & $\begin{array}{c}\text { Flexural } \\
\text { Strength } \\
\text { (Mpa) }\end{array}$ \\
\hline \multirow{13}{*}{$\mathrm{W}_{1}$} & \multirow[t]{2}{*}{ - } & 0 & LG & $\mathrm{RB}$ & 15.20 & 0.492 & 3.35 \\
\hline & & 2 & LG & $\mathrm{RB}$ & 21.28 & 0.491 & 1.50 \\
\hline & \multirow[t]{3}{*}{100} & 6 & LG & $\mathrm{RB}$ & 13.94 & 0.662 & 1.70 \\
\hline & & 10 & LG & $\mathrm{RB}$ & 13.86 & 0.447 & 8.34 \\
\hline & & 2 & LG & $\mathrm{RB}$ & 19.53 & 0.307 & 1.87 \\
\hline & \multirow[t]{3}{*}{300} & 6 & LG & $\mathrm{RB}$ & 15.29 & 0.723 & 3.65 \\
\hline & & 10 & LG & $\mathrm{RB}$ & 14.37 & 0.546 & 6.86 \\
\hline & & 2 & LG & $\mathrm{RB}$ & 16.15 & 0.307 & 3.42 \\
\hline & \multirow[t]{3}{*}{500} & 6 & LG & $\mathrm{RB}$ & 15.86 & 0.747 & 4.00 \\
\hline & & 10 & LG & $\mathrm{RB}$ & 14.71 & 0.668 & 6.20 \\
\hline & & 2 & LG & $\mathrm{RB}$ & 15.32 & 0.122 & 5.05 \\
\hline & \multirow[t]{2}{*}{800} & 6 & LG & $\mathrm{RB}$ & 16.19 & 0.970 & 6.35 \\
\hline & & 10 & LG & $\mathrm{RB}$ & 14.76 & 0.670 & 5.94 \\
\hline \multirow{13}{*}{$\mathrm{W}_{2}$} & \multirow[t]{2}{*}{ - } & 0 & DG & $\mathrm{RB}$ & 13.13 & 0.925 & 6.54 \\
\hline & & 2 & DG & $\mathrm{RB}$ & 17.52 & 0.941 & 3.42 \\
\hline & \multirow[t]{3}{*}{100} & 6 & DG & $\mathrm{RB}$ & 11.33 & 0.747 & 3.68 \\
\hline & & 10 & DG & $\mathrm{RB}$ & 10.86 & 0.769 & 8.72 \\
\hline & & 2 & DG & $\mathrm{RB}$ & 16.39 & 0.490 & 4.00 \\
\hline & \multirow[t]{3}{*}{300} & 6 & $\mathrm{DG}$ & $\mathrm{RB}$ & 13.42 & 0.723 & 4.55 \\
\hline & & 10 & DG & $\mathrm{RB}$ & 11.19 & 0.952 & 7.67 \\
\hline & & 2 & DG & $\mathrm{RB}$ & 14.84 & 0.369 & 5.64 \\
\hline & \multirow[t]{3}{*}{500} & 6 & DG & $\mathrm{RB}$ & 14.17 & 0.743 & 5.60 \\
\hline & & 10 & $\mathrm{DG}$ & $\mathrm{RB}$ & 12.51 & 1.243 & 6.83 \\
\hline & & 2 & DG & $\mathrm{RB}$ & 14.68 & 0.246 & 5.92 \\
\hline & \multirow[t]{2}{*}{800} & 6 & $\mathrm{DG}$ & $\mathrm{RB}$ & 14.28 & 0.800 & 6.95 \\
\hline & & 10 & $\mathrm{DG}$ & $\mathrm{RB}$ & 13.04 & 1.700 & 6.03 \\
\hline
\end{tabular}

$\mathrm{DG}=$ dark grey; $\mathrm{LG}=$ light grey; $\mathrm{RB}=$ reddish brown . 

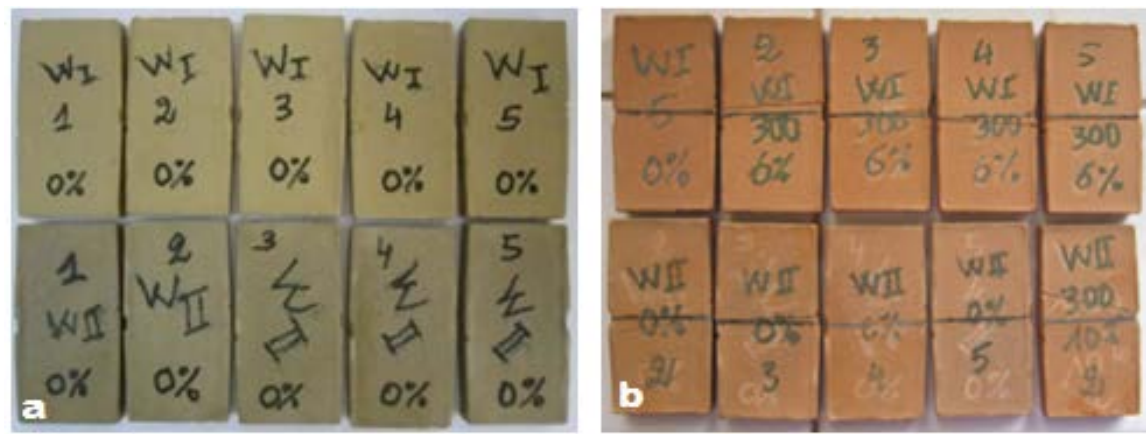

Figure 5. Raw (a) and fired material (b).
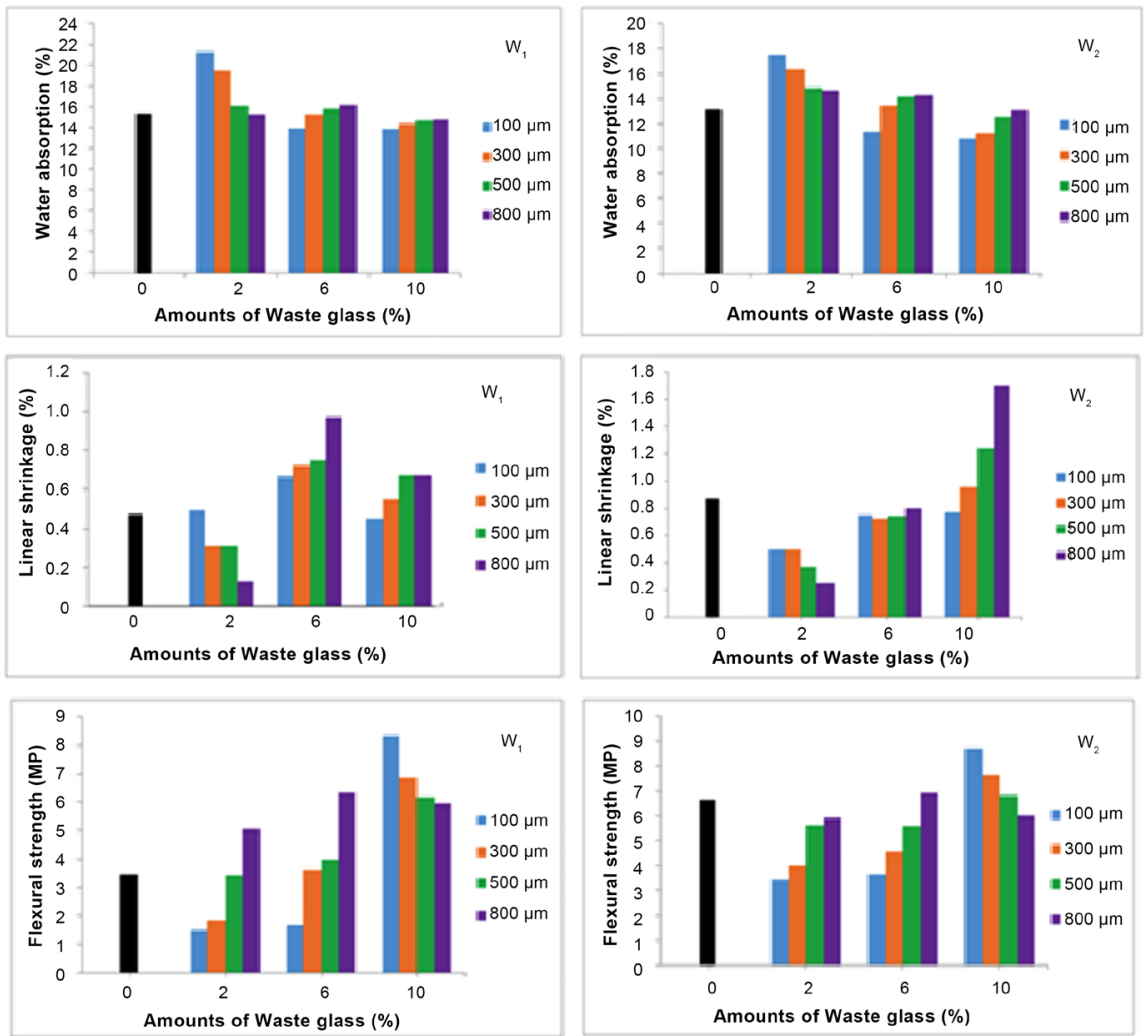

Figure 6. Physical and mechanical characteristics of fired clays.

phase (hematite), dissolution of quartz via the vitreous phase generated by the fusion of waste glass (Figure 8). Anyhow, an increase of linear shrinkage of fired products is an expression of their reactivity and this is emphasized when the additive waste glass increases up to $10 \%$.

The water absorption percentage decreases when the percentage of waste glass increases up to $10 \%$ (Figure 6). This behavior is attributed to the vitreous phase by waste glass. In fact the amount of this vitreous phase increases with increase of waste glass percentage and gradually, this viscous phase wraps up particles of the samples. Hence progressive decrease of voids within the samples leads to the decrease of water absorption percentage [21] [22] [23].

Flexural strength is a characteristic which is strongly dependent on voids: The 
lower there are voids, the higher are the values of flexural strength of fired products. As the mass percentage of waste glass increases up to $10 \%$, there is a noticeable tendency of increase of flexural strength of fired samples [24].

As already mentioned above, these results are in accordance with the variation of water absorption as a consequence of viscous flow mechanism, inducing densification through consolidation of particles of fired samples. Therefore, the vitrification causes the reduction of porosity and samples experience increase of mechanical strength [15]-[27]. Thus, with respect to above mentioned, this process can be technologically applied for the production of fired bricks, roofing tiles, rustic floor or wall tiles and related materials which could be used for masonry purpose and sustainable development.

The observation of the specimen which without additive shows that the pore radius is between 0.5 microns and 2 microns (Figure 7). With the addition of $100 \mu \mathrm{m}$ glass at $10 \%$, the formation of a liquid phase is observed with a decrease in porosity compared to that without addition. The size of $100 \mu \mathrm{m}$ of glass strongly influences the microstructure by a considerable reduction of the pores by formation of liquid phases. With the addition of glass pores are less to less connected and more isolated.

Figure 8 and Figure 9 show the XRD results of some fired clays: 1): $\mathrm{W}_{1}$ and
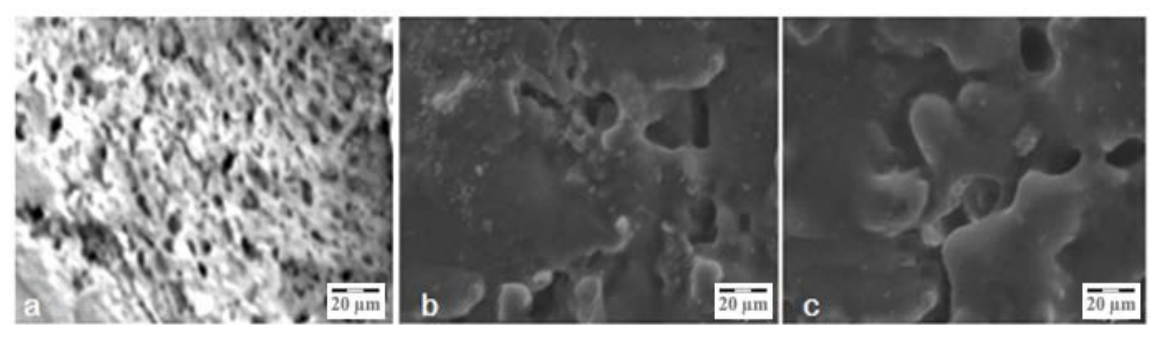

Figure 7. Microstructure of the fired clays: (a) without additive; (b) $\mathrm{W}_{1}$ with additive (100 $\mu \mathrm{m}, 10 \%)$; (c) $\mathrm{W}_{2}$ with additive $(100 \mu \mathrm{m}, 10 \%)$.

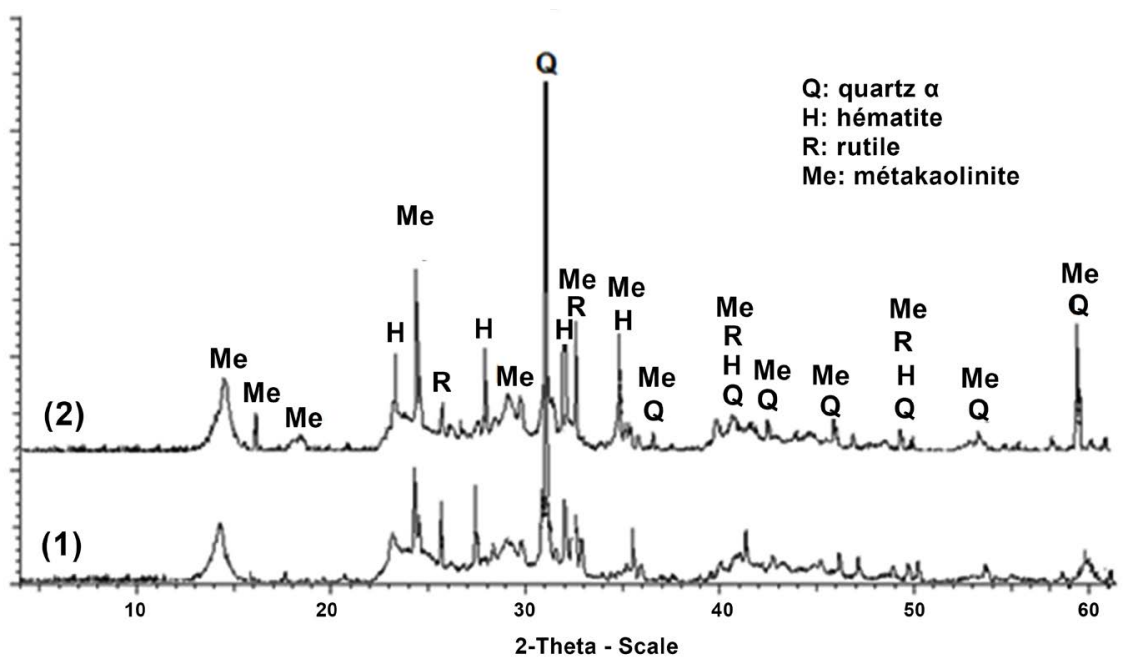

Figure 8. XRD patterns of fired clays: (1): $\mathrm{W}_{1}$ without additive, (2): $\mathrm{W}_{1}$ with additive (100 $\mu \mathrm{m}, 10 \%)$. 


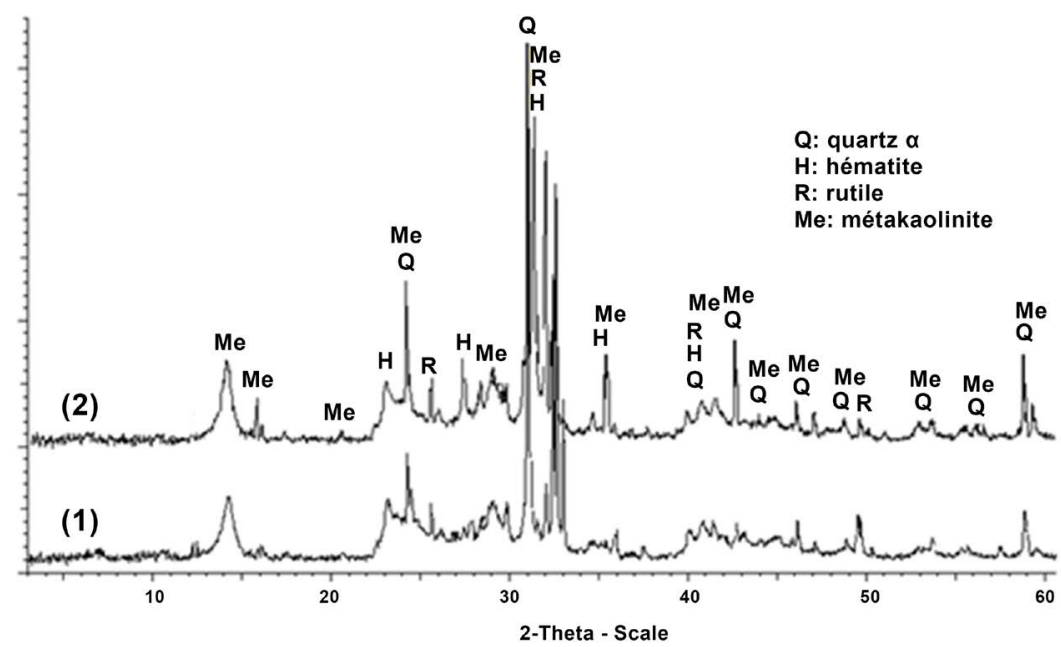

Figure 9. XRD patterns of fired clays: (1): $\mathrm{W}_{2}$ without additive, (2): $\mathrm{W}_{2}$ with additive (100 $\mu \mathrm{m}, 10 \%)$.

$\mathrm{W}_{2}$ without additive, 2): $\mathrm{W}_{1}$ and $\mathrm{W}_{2}$ with additive $(100 \mu \mathrm{m}, 10 \%)$. X-ray diffraction patterns show the presence of different phases that are identified as: quartz $a$, metakaolinite, rutile and hematite. In Figure 9 , it can be noticed that, by increasing the content of glass in bricks $(10 \%, 100 \mu \mathrm{m})$, the intensity of the peak of the quartz phase decreases while the intensity of the peak of metakaolinite phase increases; the same effect can be appreciated for compositions with the same content of glass but with reduced particle size (Figure 9). It is proposed that, at medium temperature, most of the silica in quartz phase contained in the specimens remain unreacted but some amount of quartz can be transformed into metakaolinite.

\section{Conclusion}

The influence of colorless waste glass on the mineralogical, microstructural and mechanical properties of terracotta made from local Wack clay was explored. With the addition of glass with a siliceous amorphous phase, it is possible to increase the content of the liquid phases during sintering. The amount of mullite is thus improved and hence the microstructure of the parts is more condensed with low porosities. The mechanical properties closely related to the mineralogy and the microstructures of the parts were significantly improved. The best performing products are obtained at $100 \mu \mathrm{m}$ with $10 \%$ glass as fluxes. The contribution of glass in the melting temperature which is around $700^{\circ} \mathrm{C}$ can allow significant energy savings, especially in developing countries such as Cameroon.

\section{Conflicts of Interest}

The authors declare no conflicts of interest regarding the publication of this paper.

\section{References}

[1] Grim, R.E. (1968) Clay Mineralogy. 2nd Edition, McGraw-Hill, New York, 596 p. 
[2] Bauluz, B., Mayayo, M.J., Fernández-Nieto, C., Cultrone, G. and González López, J.M. (2003) Assessment of Technological Properties of Calcareous and Non-Calcareous Clays Used for the Brick-Making Industry of Zaragoza (Spain). Applied Clay Science, 24, 121-126. https://doi.org/10.1016/S0169-1317(03)00152-2

[3] Hajjaji, M., Kacim, S. and Boulmane, M. (2002) Mineralogy and Firing Characteristics of a Clay from the Valley of Ourika (Morocco). Applied Clay Science, 21, 203-212. https://doi.org/10.1016/S0169-1317(01)00101-6

[4] Sánchez, E., Ginés, F., Agramunt, J. and Monzó, M. (1998) Control de calidad de las arcillas empleadas en la fabricación de los soportes de baldosas cerámicas. Proceedings Qualicer, 98, 97-112.

[5] Guiraudie, C. (1955) Notice explicative sur la feuille Ngaoundéré Ouest, accompagnée de la carte géologique de reconnaissance au 1/500000, levés effectuées de 1949 à 1953. Imprimerie Nationale, Paris, 23.

[6] Nkouandou, O.F., Ngounouno, I. and Deruelle, B. (2010) Géochimie des laves basaltiques récentes des zones Nord et Est de Ngaoundéré (Cameroun, Plateau de l'Adamaoua, Afrique centrale): Pétrogenèse et naturede la source. International Journal of Biological and Chemical Sciences, 4, 984-1003. https://doi.org/10.4314/ijbcs.v4i4.63038

[7] Akoumou, M.N., Nouayou, R.T., Tabod, C. and Manguelle-Dicoum, E. (2011) Evidence for Precambrian Faulting in the Tibati-Adamawa Region of Cameroonusing the Audiomagnetotelluric Method. Geofísica Internacional, 50, 129-146.

[8] Zo'o Zame, P., Nzeukou Nzeugang, A., Uphie Chinje, M., Mache, J.R., Ndifor, D.A. and Nni, J. (2016) Mapping and Geotechnical Characterization of Some Local Construction Materials for the Adamawa Region of Cameroon. British Journal of Applied Science \& Technology, 17, 1-13. https://doi.org/10.9734/BJAST/2016/27887

[9] Tiffo, E., Elimbi, A., Dika, M.J. and Tchamba, A.B. (2015) Red Ceramics Produced from Mixtures of Kaolinite Clay and Waste Glass. Brazilian Journal of Sciences \& Technology, 2, 4. https://doi.org/10.1186/s40552-015-0009-9

[10] Norme Française NF-P-18-554 (1979) Mesures des masses volumiques, porosité, coefficient d'absorption d'eau et teneur en eau des gravillons et cailloux, France.

[11] Norme Européenne EN-100 (1982) Détermination de la résistance à la flexion.

[12] Mosser, C.H., Brillanceau, A. and Besnus, Y. (1990) Relationship between Sediments and Their Igneous Source Rocks Using Clay Mineral Multielement Chemistry: The Cenozoic Lacustrine Anloua Basin (Adamaoua, Cameroon). Chemical Geology, 90, 319-342. https://doi.org/10.1016/0009-2541(91)90107-3

[13] Raimondo, M., Zanelli, C., Matteucci, F., Guarini, G., Dondi, M. and Labrincha, J.A. (2007) Effect of Waste Glass (TV/PC Cathodic Tube and Screen) on Technological Properties and Sintering Behaviour of Porcelain Stoneware Tiles. Ceramics International, 33, 615-623. https://doi.org/10.1016/j.ceramint.2005.11.012

[14] Bich, C., Ambroise, J. and Péra, J. (2009) Influence of Degree of Dehydroxylation on the Pozzolanic Activity of Metakaolin. Applied Clay Science, 44, 194-200. https://doi.org/10.1016/j.clay.2009.01.014

[15] Hafid, K.E. and Hajjaji, M. (2015) Effects of the Experimental Factors on the Microstructure and the Properties of Cured Alkali-Activated Heated Clay. Applied Clay Science, 116-117, 202-210. https://doi.org/10.1016/j.clay.2015.03.015

[16] Andreola, F., Barbieri, L., Karamanova, E., Lancellotti, I. and Pelino, M. (2008) Recycling of CRT Panel Glass as Fluxing Agent in the Porcelain Stoneware Tile Production. Ceramics International, 34, 1289-1295. https://doi.org/10.1016/j.ceramint.2007.03.013 
[17] Dondi, M., Guarini, G., Raimondo, M. and Zanelli, C. (2009) Recycling PC and TV Waste Glass in Clay Bricks and Roof Tiles. Waste Management, 29, 1945-1951. https://doi.org/10.1016/j.wasman.2008.12.003

[18] Tchakouté, K.H., Elimbi, A., Yanne, E. and Djangang, N.C. (2013) Utilization of Volcanic Ashes for the Production of Geopolymers Cured at Ambient Temperature. Cement and Concrete Composites, 38, 75-81. https://doi.org/10.1016/j.cemconcomp.2013.03.010

[19] Elimbi, A., Tchakouté, H.K. and Njopwouo, D. (2011) Effects of Calcination Temperature of Kaolinite Clays on the Properties of Geopolymer Cements. Construction and Building Materials, 25, 2805-2812.

https://doi.org/10.1016/j.conbuildmat.2010.12.055

[20] Park, Y.J. and Heo, J. (2002) Conversion to Glass-Ceramics from Glasses Made by MSW Incinerator Fly Ash for Recycling. Ceramics International, 28, 689-694. https://doi.org/10.1016/S0272-8842(02)00030-5

[21] Vieira, C.M.F., Sanchez, R. and Monteiro, S.N. (2008) Characteristics of Clays and Properties of Building Ceramics in the State of Rio de Janeiro, Brazil. Construction and Building Materials, 22, 781-787.

https://doi.org/10.1016/j.conbuildmat.2007.01.006

[22] Phonphuak, N. and Thiansem, S. (2012) Using Charcoal to Increase Properties and Durability of Fired Test Briquettes. Construction and Building Materials, 29, 612-618. https://doi.org/10.1016/j.conbuildmat.2011.11.018

[23] Pérez-Villarejo, L., Martínez-Martínez, S., Carrasco-Hurtado, B., Eliche-Quesada, D., Ureña-Nieto, C. and Sánchez-Soto, P.J. (2015) Valorization and Inertization of Galvanic Sludge Waste in Clay Bricks. Applied Clay Science, 105-106, 89-99. https://doi.org/10.1016/j.clay.2014.12.022

[24] Sultana, M.S., Ahmed, A.N., Zaman, M.N., Rahman, M.A., Biswas, P.K. and Nandy, P.K. (2015) Utilization of Hard Rock Dust with Red Clay to Produce Roof Tiles. Journal of Asian Ceramic Societies, 3, 22-26. https://doi.org/10.1016/j.jascer.2014.10.005

[25] Chen, Y., Zhang, Y., Chen, T., Zhao, Y. and Bao, S. (2011) Preparation of Eco-Friendly Construction Bricks from Hematite Tailings. Construction and Building Materials, 25, 2107-2111. https://doi.org/10.1016/j.conbuildmat.2010.11.025

[26] Emrullahoglu, A.C.B. (2014) Effect of Borogypsum on Brick Properties. Construction and Building Materials, 59, 195-203. https://doi.org/10.1016/j.conbuildmat.2014.02.012

[27] Bernhardt, M., Justnes, H., Tellesbo, H. and Wiik, K. (2014) The Effect of Additives on the Properties of Lightweight Aggregates Produced from Clay. Cement and Concrete Composites, 53, 233-238.

https://doi.org/10.1016/j.cemconcomp.2014.07.005 